\title{
Protein Wnt-11
}

National Cancer Institute

\section{Source}

National Cancer Institute. Protein Wnt-11. NCI Thesaurus. Code C21451.

Protein Wnt-11 (354 aa, $39 \mathrm{kDa}$ ) is encoded by the human WNT 11 gene. This protein is involved in binding to and stimulating signaling by frizzled family receptors. 